Article

\title{
Hydrochemical characteristics and water quality assessment of surface water at Xiahe county in Tibetan Plateau pastoral of China
}

\author{
Qian Zhang 1,2, Shengli Wang 1,2, Muhammad Yousaf ${ }^{3}$, Shuixian Wang ${ }^{4}$, Zhongren Nan ${ }^{\text {, }}$ \\ Jianmin Ma ${ }^{1}$, Depeng Wang ${ }^{1}$, Fei Zang ${ }^{1}$ \\ 1 Key Laboratory for Environmental Pollution Prediction and Control, College of Earth and Environmental \\ Sciences, Lanzhou University, Tianshui South Road 222, Lanzhou 730000, China \\ 2 Key Laboratory of Western China's Environmental Systems (Ministry of Education), College of Earth and \\ Environmental Sciences, Lanzhou University, Lanzhou 730000, China. \\ 3 Department of Chemistry and Biology, Ryerson University, Toronto, M5B 2K3, Canada \\ 4 College of Earth and Environmental Sciences, Lanzhou University, Lanzhou 730000, China \\ * Correspondence: wangshengl@lzu.edu.cn; Tel.: +86-18693930525
}

\begin{abstract}
Water quality assessment in pastoral of Tibetan Plateau, which is water sources for about $40 \%$ of world's population and the runoff-yield area of Yellow rivers, is very important. In this paper, Xiahe county which belongs to Tibetan Plateau pastoral was investigated. Six parameters(via, chloride, COD, ammonia nitrogen, nitrate, fluoride, sulfate) were selected to assess the water quality and health degree by using fuzzy comprehensive evaluation methods. The hydrochemical type in surface water was of $\mathrm{HCO}_{3}-\mathrm{Mg}^{2+}-\mathrm{C}^{2+}$ type. The cations and anions in surface water were mainly from weathering and dissolution of carbonate rock. Results showed that the water quality in all 69 sampling sites was all of class I. The integrated health degree reached more than 0.85 and the health rate were $100 \%$. Although ammonia nitrogen was regarded as the main contamination factor, but it had a little effect on the entire body of water. Overall, the surface water qualities of most samples in Xiahe County was good condition.
\end{abstract}

Keywords: Surface water; Tibetan Plateau pastoral area; Xiahe County; Hydrochemical characteristics; Fuzzy comprehensive method; Water quality

PACS: J0101

\section{Introduction}

The Tibetan Plateau is water sources for about $40 \%$ of world's population ${ }^{[1]}$ so that it is called the "Water Tower of Asia" which feeds the Indus, Ganges, Brahmaputra, Yangtze and Yellow rivers ${ }^{[2,3]}$. As for water will become, oil and an important controlling component in restricting the development of the global economy and society of the $21^{\text {st }}$ century ${ }^{[4,5]}$.Although climate warming has caused to increasing amounts of meltwater on the Tibetan Plateau, but much of this water can't used, reducing the water available for downstream areas and limiting the water consumption of these areas ${ }^{[1,6-}$ ${ }^{81 . T h e r e ~ i s ~ a ~ l a c k ~ o f ~ u n d e r s t a n d i n g ~ a n d ~ k n o w i n g ~ c o n c e r n i n g ~ t h e ~ w a t e r ~ q u a l i t y ~ o f ~ t h e s e ~ w a t e r ~ r e s o u r c e ~}$ except its importance, Barnett and Huang found that the resultant changes in hydrological conditions on the quality and availability of the water from the Plateau. In recent years, a great many survives have been demonstrated runoff ${ }^{[9]}$, precipitation, etc, on the water cycle components of the plateau[ ${ }^{[3]}$, alpine lake water environment changes on the Tibetan Plateau ${ }^{[10]}$. But for surface water, only Zheng carried out the Tibetan surface water in 1956 which studies mainly focused on major ions in saline lakes on the Tibetan Plateau is the most comprehensive study ${ }^{[1]}$ and surface water quality of Yangtze Estuary ${ }^{[2]}$.

Surface water is the most momentous resource for people's lives, irrigation and industry in Tibetan Plateau pastoral area of Gansu Province. Surface water consists of water that flows in the form of rivulets, springs, streams and rivers or gets it collect to form ponds, lakes and sea[13]. In 
1981,surface water was considered to be able to solve the problem of drinking water, However, by the end of $20^{\text {th }}$ century the issues of the severe drought and desertification of surface are becoming more and more serious, groundwater is now considered as one of the most momentous ways to resolve the drinking water problem ${ }^{[14]}$. Additionally, there are two main reasons for problem related to surface water. Firstly, surface water can be contaminated by anthropogenic activities ${ }^{[15,16]}$ in: nonpoint sources and point sources. non-point source pollutants are washed from the earth's surface by storm runoff and enter water bodies of their own accord ${ }^{[17]}$, whereas point sources pollutants are directed and released into water bodies in man-made pipes ${ }^{[18,19]}$. Secondly, agricultural activities degrade water quality directly or indirectly by increasing a mass of fertilizers, pesticides and dairy manures in the cropland to fulfill human food demand ${ }^{[20,21]}$. So surface water quality is a hot topic as well as a matter of serious concern today. Also, it is vital to human health and because the quality of crops(and thus grains) is being effected by the soil and the environment is getting polluted.[22,23]. Surface water quality and availability have been deteriorated due to ongoing increase in population, industrialization, and anthropogenic activities ${ }^{[24-26]}$.Increase in water pollution not only deteriorate the water quality but also endangers human health, balance in ecosystems, economic development, and social prosperity ${ }^{[23]}$.The surface water quality is one of the most sensitive issues all over the world and is potentially being influenced by many anthropogenic and natural factors ${ }^{[27,28]}$. Due of this reason, water quality assessment has become a significant part of water resource management, research and programming. besides, providing a representative and reliable estimation of the quality of surface water is necessary ${ }^{[26,29]}$. A certain surface water quality may be good enough for irrigation purpose but not be good for drinking purpose. Consequently, water quality monitoring is important to the protection of people's health, agriculture, industry, recreation, tourism and ecosystems ${ }^{[27]}$ and the water quality assessment is mostly based on hydrochemical analysis ${ }^{[22]}$.

Currently, studies on fuzzy comprehensive evaluation, hydrochemical characteristics and water quality assessment of water are mainly concentrated on river, estuary wetland, and lake areas.[30]. However, The surface water study in Tibetan Plateau pastoral area was neglected and theory based study is perfect and mature. Xiahe County is not only belongs to Tibetan Plateau and the National Nature Reserve of Three Rivers Source but the runoff-yield area of the Yellow River. consequently, this paper taking Xiahe county as an example to study hydrochemical characteristics and the quality of surface water of the Tibetan Plateau pastoral area. In this research, 69 surface water sampling points were used to analyze the quality of water in Xiahe County while keeping in mind the distribution of major river systems and the characteristics of the surface water distribution throughout the County. For this study, six important water quality indicators were used which include chloride, chemical oxygen demand(COD), ammonia nitrogen, nitrate, fluoride, and sulfates. These parameters are widely used in surface water analysis. The fuzzy comprehensive evaluation method, water quality index (WQI), field research, multivariate statistical methods (such as Spearman's correlation coefficient), and the piper's trilinear diagram, for comprehensive evaluation were applied to analyze the hydrochemical characteristic and quality of surface water. These multivariate statistical methods have successfully used in numerous studies [31,32] for the hydrochemical characteristic of surface water and to evaluate surface water quality. This study reveals the correlation between surface water samples of anions and cations. Determined hydrochemical type of the surface water, ralates surface water quality with health and analyzed its main pollution factor to evaluate the suitability of their waters for drinking and agricultural purpose. In addition, effective measures were put forward to protect the quality of the surface water. The findings of the study could be used as recommendations to prevent/manage surface water pollution and to preserve ecological balance in Tibetan Plateau pastoral area.

\section{General Situation of Study area}

Xiahe County $\left(101^{\circ} 54^{\prime}-103^{\circ} 25^{\prime} \mathrm{E}, 34^{\circ} 32^{\prime}-35^{\circ} 34^{\prime} \mathrm{N}\right)$ is located in the southern part of Gansu Province, the eastern edge of the Qinghai-Tibetan plateau, east of Hezuo city , north of Linxia state, west side of Qinghai province at an altitude of approximately $3000-4200 \mathrm{~m}$ above the sea leve[ [33-35], it is a pure animal husbandry county with a population of 2.56 million, is one of the province in the 
north-western region ${ }^{[34]}$. The average annual temperature is $2.6^{\circ} \mathrm{C}$ with the highest being $28.9^{\circ} \mathrm{C}$, the lowest being $-24.6^{\circ} \mathrm{C}$ and with a harsh, cold and wet climate. The average annual precipitation is approximately $516 \mathrm{~mm}$, and is concentrated in the months of July and August ${ }^{[36]}$.On account of the many abundant storm water, tributaries the snow-capped mountains and lakes that constitute a integral water conservation system of the Yellow River, as the Yellow River 'reservoir'[37]. Daxia and Tao rivers, which flow through Xiahe County, belongs to the Yellow River 'reservoir'. Grass industry is a crucial advantage resource of Xiahe County.

\section{Materials and Methods}

\subsection{Water sampling}

In total, 69 surface water sampling sites were chosen throughout Xiahe County of Tibetan Plateau pastoral area, As for each sampling point, triplicate water samples, which were collected in $500 \mathrm{ml}$ plastic bottles. The collected samples of surface water were immediately transferred, without any addition of a chemical stabilizer, to the laboratory at Lanzhou university environmental science research institute for the chemical analysis ${ }^{[38]}$. All water samples were stored below $4^{\circ} \mathrm{C}$. The spatial distribution map of surface water sampling sites in Xiahe County is shown in Figure 1.

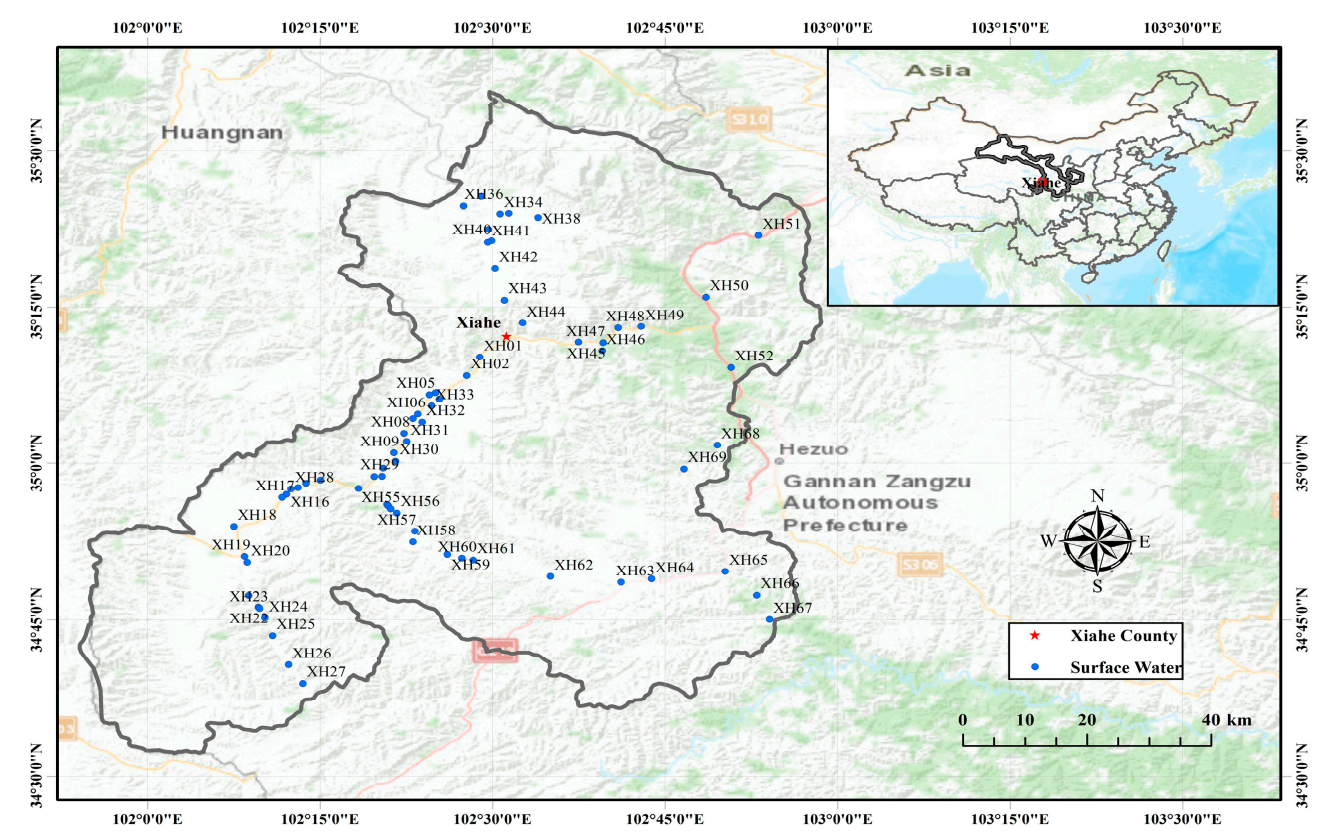

Figure 1. Distribution map of surface water sampling sites

\subsection{Analytical techniques}

Table 1. Analytical method used to the surface water

\begin{tabular}{|c|c|c|}
\hline Quality parameter & Symbol & Method used \\
\hline Turbidity & Turbidity & Turbidity meter \\
\hline Chemical Oxygen Demend & COD & Potassium dichromate method \\
\hline $\mathrm{PH}$ & $\mathrm{PH}$ & PH meter \\
\hline Potassium/Calcium/Sodium/Magnesium & $\mathrm{K}^{+} / \mathrm{Ca}^{2+} / \mathrm{Na}^{+} / \mathrm{Mg}^{2+}$ & $\begin{array}{l}\text { Inductively coupled plasma optical emission } \\
\text { spectroscopy(ICP-OES) }\end{array}$ \\
\hline Ammonium(or ammonia cation) & $\mathrm{NH}_{4}^{+}$ & Nesslers reagent photometry \\
\hline Fluorine/Nitrate nitrogen & $\mathrm{F}-/ \mathrm{NO}_{3}^{-}$ & Fluorine ion electrode \\
\hline Chloride(or chlorine anion) & $\mathrm{Cl}^{-}$ & AgNO3 titration \\
\hline Bicarbonate & $\mathrm{HCO}_{3}^{-}$ & Acid-base titration \\
\hline electrical conductivity & EC & electrical conductivity meter \\
\hline Sulphate & $\mathrm{SO} 42^{-}$ & $\begin{array}{l}\text { Barium chromate indrict atomic absorption } \\
\text { spectrophotometry }\end{array}$ \\
\hline
\end{tabular}


The water quality parameters monitored each water sample includes, turbidity, COD, $\mathrm{pH}$, calcium, potassium, sodium, magnesium, ammonia, nitrate, fluoride, EC, etc. Along with the on-site measurement of the $\mathrm{pH}$ and conductivity was done due to expected change in the measurement during the process transport and storage [38-41], Analytical methods and parameters summarized in Table 1 are based on standard methods founded for surface water monitoring in Chinal[4].

\subsection{Assessment methods of surface water}

Fuzzy comprehensive evaluation (FCE) is a quantitative scientific evaluation method, proposed by LA. Zadeh, an U.S.expert in control theory ${ }^{[33]}$, and the contributions of multiple related factors are comprehensively considered according to weight factors, and the fuzziness is decreased by using membership functions ${ }^{[4,45]}$ which is suitable for making decisions in vague and imprecise system. FCE has been widely applied in many fields, such as environmental field[46,47], agriculture field ${ }^{[43,48] \text {, }}$ engineering field ${ }^{[49,50]}$, and other fields ${ }^{[5,51-53]}$ as well as to solve the fuzzy and difficult to quantify characteristics of the problem ${ }^{[54]}$. Water quality management is characterized by imprecision in objectives and water quality standards. The application of fuzzy comprehensive evaluation method involves making of the evaluation theory and method based on comparing the rigorous mathematical model, by fuzzy level of judgment and comprehensive health degree calculation. Therefore, the advantage and disadvantage of water quality can be observed visually.

The principle procedure of FCE includes establishing the evaluation factor (via $U=\left\{U_{1}, U_{2}, U_{3}, \ldots U_{m}\right\}$ ) set and grading level (via $\left.V=\left\{V_{1}, V_{2}, V_{3}, \ldots V_{n}\right\}\right)$ set of evaluated object. This membership function with each category is expressed as ${ }^{[5]}$ :

The membership function of level 1 is :

$$
r_{i j}=\left\{\begin{array}{cl}
1 & \left(c_{i} \leq s_{i j}\right) \\
\left(s_{i j+1}-c_{i}\right) /\left(s_{i j+1}-s_{i j}\right) & \left(s_{i j}<c_{i}<s_{i j+1}\right) \\
0 & \left(c_{i} \geq s_{i j+1}\right)
\end{array}\right.
$$

The membership function from level 2 to $(\mathrm{n}-1)$ is:

$$
r_{i j}=\left\{\begin{array}{cr}
\left(c_{i}-s_{i j-1}\right) /\left(s_{i j}-s_{i j-1}\right) & \left(s_{i j-1}<c_{i}<s_{i j}\right) \\
\left(s_{i j+1}-c_{i}\right) /\left(s_{i j+1}-s_{i j}\right) & \left(s_{i j}<c_{i}<s_{i j+1}\right) \\
0 & \left(c_{i} \leq s_{i j-1} \text { or } c_{i} \geq s_{i j+1}\right)
\end{array}\right.
$$

The membership function of last level (level $\mathrm{n}$ ) is:

$$
r_{i j}=\left\{\begin{array}{cl}
1 & \left(c_{i} \geq s_{i j}\right) \\
\left(c_{i}-s_{i j-1}\right) /\left(s_{i j}-s_{i j-1}\right) & \left(s_{i j-1}<c_{i}<s_{i j}\right) \\
0 & \left(c_{i} \leq s_{i j-1}\right)
\end{array}\right.
$$

Where, $r_{i j}$ is the fuzzy membership of indicator $i$ to class $j ; C_{i}$ is the monitoring value; $S_{i j}$ is the allowable value of water quality indicator.

The fuzzy evaluation matrix $\mathrm{R}$ is the comprehensive survey to the index of safety evaluation of surface water and would have $i$ rows and $j$ lines, that's to say $R=\left[r_{i j}\right][56]$.

$$
R=\left[r_{i j}\right]=\left[\begin{array}{cccc}
r_{11} & r_{12} & \ldots & r_{1 j} \\
r_{21} & r_{22} & \ldots & r_{2 j} \\
\vdots & \vdots & \vdots & \vdots \\
r_{i 1} & r_{i 2} & \ldots & r_{i j}
\end{array}\right]
$$


The water quality index, developed by the National Sanitation Foundation(NSF) ${ }^{[57,58]}$ is an important tool to interpret the overall status of water quality in a simple and understandable manner. Water quality index (WQI) has been extensively applied to monitor water quality in recent years, and is indeed a practical method considering critical environmental variables, which represent the pollution conditions of a water body ${ }^{[15,59-61]}$. It depicts the composite influence of different water quality parameters ${ }^{[24]}$. The weight of the water quality indicator is expressed as

$$
P_{i}=C_{i} /_{S_{i}} \quad(1-4)
$$

Where $P_{i}$ is the weight of water quality indicator $i, C_{i}$ is the monitoring value of water quality indicator $i, S_{i}$ is the mean of kinds of water quality standards limit. The normalized weight of each indicator can be calculated by using the formula:

$$
W_{i}=\left({ }^{C} / S_{i}\right) / \sum_{i=1}^{m} C_{i} / S_{i}=P_{i} / \sum_{i=1}^{m} P_{i}
$$

Where $W_{i}$ means the normalized weight of indicator $i, \sum_{i=1}^{m} P_{i}$ means the sum of weight to all water quality indicators. The fuzzy $\mathrm{W}$ consists of weight each water quality indicator. The water quality assessment by fuzzy evaluation matrix $R$ and weight coefficient matrix $W$,

$$
B=W \times R \quad(1-6)
$$

The fuzzy $B$ is the matrix of membership to each water quality class. Water samples classified to the class with the maximize membership ${ }^{[22]}$.

\section{Results and discussions}

\subsection{Hydrochemical characteristics of surface water}

\begin{tabular}{|c|c|c|c|c|c|c|c|c|}
\hline Parameter & Range & Min & Max & Mean & S.D & C.V & $\begin{array}{c}\text { Varia } \\
\text { nce }\end{array}$ & skewness \\
\hline $\mathrm{K}^{+} / \mathrm{mg} \cdot \mathrm{L}^{-1}$ & 5.34 & 0.87 & 6.20 & 2.01 & 1.04 & 0.52 & 1.08 & 1.78 \\
\hline $\mathrm{Ca}^{2+} / \mathrm{mg} \mathrm{L}^{-1}$ & 71.6 & 2.8 & 74.4 & 13.1 & 8.51 & 0.65 & 72.4 & 5.53 \\
\hline $\mathrm{Na}^{+} / \mathrm{mg} \mathrm{L}^{-1}$ & 45.6 & 2.9 & 48.5 & 7.69 & 6.89 & 0.9 & 47.4 & 3.82 \\
\hline $\mathrm{Mg}^{2+} / \mathrm{mg} . \mathrm{L}^{-1}$ & 35.2 & 5.43 & 40.6 & 14.1 & 6.04 & 0.43 & 36. & 1.92 \\
\hline F-/mg. $\mathrm{L}^{-1}$ & 0.3 & 0.064 & 0.36 & 0.13 & 0.063 & 0.48 & 0.004 & 2.05 \\
\hline $\mathrm{Cl}^{-} / \mathrm{mg} \cdot \mathrm{L}^{-1}$ & 34 & 11.7 & 45.7 & 23.8 & 6.62 & 0.28 & 43.8 & 0.36 \\
\hline $\mathrm{SO}_{4}^{2-} / \mathrm{mg} . \mathrm{L}^{-1}$ & 44.8 & 6.02 & 50.8 & 13.8 & 9.97 & 0.72 & 99.4 & 2.21 \\
\hline $\mathrm{NO}_{3}-/ \mathrm{mg} . \mathrm{L}^{-1}$ & 6.76 & 0.46 & 7.22 & 1.5 & 1.05 & 0.71 & 1.1 & 3.34 \\
\hline $\mathrm{HCO}_{3}-/ \mathrm{mg} . \mathrm{L}^{-1}$ & 213 & 24.6 & 238 & 73.6 & 36.8 & 0.5 & 1351 & 2.2 \\
\hline $\mathrm{PH}$ & 1.49 & 7.16 & 8.65 & 8.09 & 0.29 & 0.036 & 0.085 & -1.07 \\
\hline COD/mg.L $L^{-1}$ & 16.6 & 2.08 & 18.7 & 6.43 & 3.72 & 0.58 & 13.8 & 1.43 \\
\hline $\mathrm{EC} / \mu \mathrm{S} . \mathrm{cm}^{-1}$ & 596 & 130 & 726 & 353 & 111 & 0.32 & 12394 & 0.7 \\
\hline $\begin{array}{c}\text { Turbidity/NT } \\
\mathrm{U}\end{array}$ & 752 & 0.17 & 752 & 70.6 & 162 & 2.3 & 26303 & 3.34 \\
\hline
\end{tabular}

4.1.1 Descriptive statistics method

Table 2. Descriptive statistics of surface water samples

Descriptive statistics method is used for hydrochemical characteristics of surface water as shown in Table 2. Among the anionic concentrations (mg/l) :bicarbonate ranges from 24.623 to 237.861(mean: 73.624) ;chloride ranges from 11.699 to 45.731(mean: 23.849); sulfate ranges from 6.022 to 50.801(mean: 13.778). So the major anions of surface water are dominated by $\mathrm{HCO}_{3}$-and $\mathrm{Cl}^{-}$(via, $\mathrm{HCO}_{3}^{-}>\mathrm{Cl}^{-}>\mathrm{SO}_{4}{ }^{2-}$ ) The $\mathrm{HCO}_{3}$ - concentration in surface water is derived from carbonate weathering and dissolution of carbonic acid [62]. Among cationic concentrations (mg/l): magnesium ranges from 5.426 to 
40.636(mean: 14.082); calcium ranges from 2.791 to 74.389 (mean: 13.104); sodium ranges from 2.908 to 48.520 (mean: 7.685); potassium ranges from 0.866 to 6.201 (mean: 2.008), Thus the major cations are dominated by $\mathrm{Ca}^{2+}$ and $\mathrm{Mg}^{2+}\left(\mathrm{via}, \mathrm{Mg}^{2+}>\mathrm{Ca}^{2+}>\mathrm{Na}^{+}>\mathrm{K}^{+}\right)$. Therefore, the analysis results showed that the hydrochemistry types in the surface water in Xiahe County is type $\mathrm{HCO}_{3}-\mathrm{Mg}^{2+}-\mathrm{Ca}^{2+}$.The standard deviation of turbidity which is a colloidal matter that dependent on the light refractive characteristics[63] is the largest and F- is the least in surface water. The coefficient variation of turbidity is the largest in surface water, it could be effluents from agricultural return flow ${ }^{[27]}$; it did not meet the World Health Organization(WHO1996) guideline for drinking water, which is set at 5 NTU[63]. EC ranging from 130 to $726 \mu \mathrm{S} / \mathrm{cm}$, with a mean of $596 \mu \mathrm{S} / \mathrm{cm}, 24.6 \%$ samples exceed the desirable limit $500 \mu \mathrm{S} / \mathrm{cm}$ for EC. Geochemical process like evaporation, silicate weathering, sulphate reduction and oxidation process and ion exchange are mainly contributors for the large variation in EC [64]. However, as for this study area may potentially be on account of anthropogenic activities and agricultural activities.

According to the $\mathrm{WHO}^{[65]}$ standard guidelines for the $\mathrm{pH}$ values for drinking water from 6.5 to 8.5 and that of irrigation water is in the range of 6.5-8.4[4]].Accordingly most of the surface water samples have $\mathrm{pH}$ values from 7.16 to 8.65 indicating the suitability for drinking and irrigation.

\subsubsection{Piper diagram}

The piper's trilinear diagram ${ }^{[66]}$ is useful for geochemical evaluation[67], and it is a graphical presentation of the major ions to quickly determine the hydrochemical facies ${ }^{[6,69]}$ of the surface water in the study area[67], see Figure 2. However, the main weakness of the piper's trilinear diagram is that it shows the chemical character of surface water based on the relative concentration of its constituents rather than the absolute concentrations. In this graph, the major cations and anions concentrations are demonstrated in the bottom left and right triangles, respectively. It also showed the dispersion of samples between $\mathrm{Cl}^{-}$and $\mathrm{HCO}_{3}-$ dominated waters, while the majority of samples were concentrated in the $\mathrm{Mg}^{2+}$ field. Therefore, the results of water chemical characteristics showed that: the hydrochemistry types in the surface water is $\mathrm{HCO}_{3}-\mathrm{Mg}^{2+}-\mathrm{Ca}^{2+}$. It is consistent with the hydrochemical types of Qinghai Lake Basin ${ }^{[30]}$.The anions and cations in surface water could come mainly from the weather and dissolution of carbonate rock, and could also be associated with anthropogenic activities[13].

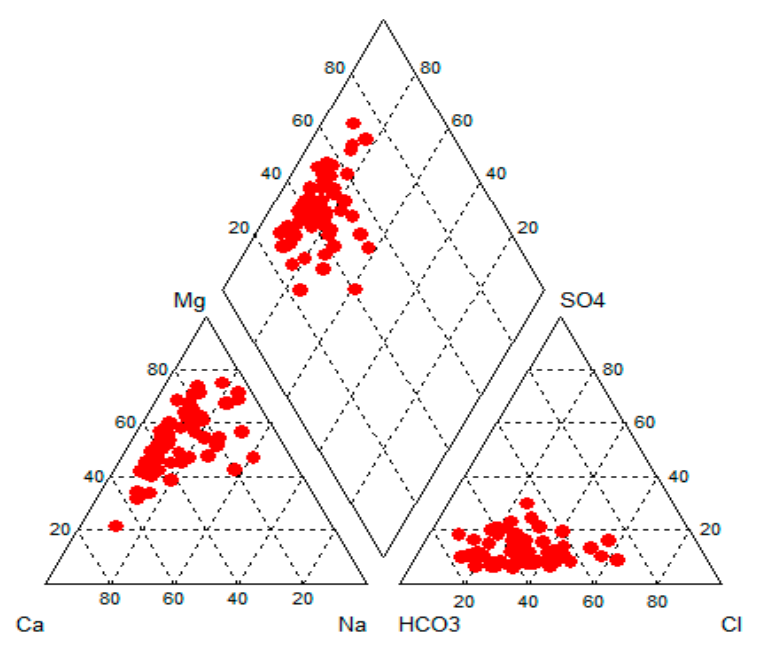

Figure 2. Pirer's trilinear diagram of surface water in Xia he County

4.1.3 Spearman's correlation coefficient 
Spearman's correlation coefficient was used to test correlations between the parameter (Table 3). A significant correlation was found between $\mathrm{pH}$ and concentrations of $\mathrm{K}^{+}$, turbidity, fluoride. A significant positive correlation was established between concentrations of $\mathrm{K}^{+}, \mathrm{Ca}^{2+}, \mathrm{Na}^{+}, \mathrm{Mg}^{2+}, \mathrm{HCO}_{3}{ }^{-}$ , $\mathrm{NO}_{3}{ }^{-}$and sulfate content of surface water. Concerning of the principal ions correlations were also found between $\mathrm{Mg}^{2+}, \mathrm{Na}^{+}$, and $\mathrm{HCO}_{3}{ }^{-}$concentrations. The content of $\mathrm{F}^{-}$and $\mathrm{K}^{+}$ions were increased with the decrease in $\mathrm{pH}$. At the same time, concentrations of $\mathrm{Ca}^{2+}, \mathrm{Mg}^{2+}, \mathrm{Na}+$ were increased with increasing concentrations of $\mathrm{HCO}_{3}^{-}$and showed a significant positive correlation $(\mathrm{r}=0.409,0.751$, 0.641 , respectively). The significant positive correlation suggests that the leading cations come from all kinds of sulfates and bicarbonates. In general, speaking $\mathrm{HCO}_{3}{ }^{-}$values were found to be highest in the samples of all seasons and sites indicating that weathering of rocks plays a major role in the geochemistry of groundwater ${ }^{[62]}$.

Table 3. Correlation matrices of hydro-chemical parameters of surface water

\begin{tabular}{|c|c|c|c|c|c|c|c|c|c|c|c|c|c|}
\hline & $\mathbf{K}^{+}$ & $\mathrm{Ca}^{2+}$ & $\mathrm{Na}^{+}$ & $\mathbf{M g}^{2+}$ & $\mathrm{SO}_{4}{ }^{2-}$ & $\mathrm{Cl}^{-}$ & $\begin{array}{l}\mathrm{HC} \\
\mathrm{O}_{3}^{-}\end{array}$ & $\mathrm{NO}_{3}{ }^{-}$ & $\mathrm{F}^{-}$ & PH & $\begin{array}{c}\text { Tubidi } \\
\text { ty }\end{array}$ & $\begin{array}{c}\text { CO } \\
\mathrm{D}\end{array}$ & $\begin{array}{l}\mathrm{E} \\
\mathrm{C}\end{array}$ \\
\hline $\mathbf{K}^{+}$ & 1 & & & & & & & & & & & & \\
\hline $\mathrm{Ca}^{2+}$ & 0.038 & 1 & & & & & & & & & & & \\
\hline $\mathrm{Na}^{+}$ & $\begin{array}{c}0.730 \\
* *\end{array}$ & $\begin{array}{c}- \\
0.022\end{array}$ & 1 & & & & & & & & & & \\
\hline $\mathbf{M g}^{2+}$ & $\begin{array}{c}0.382 \\
* *\end{array}$ & $\begin{array}{c}- \\
0.173\end{array}$ & $\begin{array}{c}0.615 \\
* *\end{array}$ & 1 & & & & & & & & & \\
\hline $\mathrm{SO}_{4}{ }^{2-}$ & $\underset{* *}{0.635}$ & $\underset{* *}{0.326}$ & $\underset{* *}{0.806}$ & $\underset{* *}{0.534}$ & 1 & & & & & & & & \\
\hline $\mathrm{Cl}^{-}$ & 0.065 & $\begin{array}{c}- \\
0.070\end{array}$ & 0.157 & 0.131 & 0.030 & 1 & & & & & & & \\
\hline $\mathrm{HCO}_{3}^{-}$ & $\begin{array}{c}0.470 \\
* *\end{array}$ & $\begin{array}{c}0.409 \\
* *\end{array}$ & $\begin{array}{c}0.641 \\
* *\end{array}$ & $\begin{array}{c}0.751 \\
* *\end{array}$ & $\begin{array}{c}0.690 \\
* *\end{array}$ & $\begin{array}{c}- \\
0.15 \\
8\end{array}$ & 1 & & & & & & \\
\hline $\mathrm{NO}_{3}{ }^{-}$ & $\begin{array}{c}0.644 \\
* *\end{array}$ & $\begin{array}{c}- \\
0.143\end{array}$ & $\begin{array}{c}0.848 \\
* *\end{array}$ & $\begin{array}{c}0.502 \\
* *\end{array}$ & $\begin{array}{c}0.742 \\
* *\end{array}$ & $\begin{array}{c}0.17 \\
9\end{array}$ & $\begin{array}{c}0.403 \\
* *\end{array}$ & 1 & & & & & \\
\hline F- & $\begin{array}{c}0.647 \\
* *\end{array}$ & 0.152 & $\begin{array}{c}0.527 \\
* *\end{array}$ & $\begin{array}{c}0.336 \\
* *\end{array}$ & $\begin{array}{c}0.469 \\
* *\end{array}$ & $\begin{array}{c}0.10 \\
3\end{array}$ & $\begin{array}{c}0.458 \\
* *\end{array}$ & $\begin{array}{c}0.489 \\
* *\end{array}$ & 1 & & & & \\
\hline PH & $\begin{array}{c}- \\
0.332 \\
* *\end{array}$ & $\begin{array}{c}- \\
0.122\end{array}$ & $\begin{array}{c}- \\
0.108\end{array}$ & $\begin{array}{c}- \\
0.087\end{array}$ & $\begin{array}{c}- \\
0.200\end{array}$ & $\begin{array}{c}- \\
0.05 \\
9\end{array}$ & $\begin{array}{c}- \\
0.109\end{array}$ & $\begin{array}{c}- \\
0.095\end{array}$ & $\begin{array}{c}- \\
0.331 \\
* *\end{array}$ & 1 & & & \\
\hline $\begin{array}{l}\text { Tubid } \\
\text { ity }\end{array}$ & $\begin{array}{c}0.314 \\
* *\end{array}$ & $\begin{array}{c}- \\
0.006\end{array}$ & $\begin{array}{c}- \\
0.060\end{array}$ & $\begin{array}{c}- \\
0.033\end{array}$ & 0.015 & $\begin{array}{c}0.13 \\
1\end{array}$ & $\begin{array}{c}- \\
0.091\end{array}$ & 0.074 & $\begin{array}{c}0.492 \\
* *\end{array}$ & $\begin{array}{c}- \\
0.315 \\
* *\end{array}$ & 1 & & \\
\hline COD & $\begin{array}{c}0.318 \\
* *\end{array}$ & $\begin{array}{c}- \\
0.085\end{array}$ & 0.187 & 0.031 & 0.126 & $\begin{array}{c}0.08 \\
0\end{array}$ & $\begin{array}{c}- \\
0.022\end{array}$ & 0.169 & 0.167 & $\begin{array}{c}- \\
0.122\end{array}$ & -0.002 & 1 & \\
\hline EC & $\begin{array}{c}0.530 \\
* *\end{array}$ & $\begin{array}{c}- \\
0.016\end{array}$ & $\begin{array}{c}0.666 \\
* *\end{array}$ & $\begin{array}{c}0.801 \\
* *\end{array}$ & $\begin{array}{c}0.617 \\
* *\end{array}$ & $\begin{array}{c}0.07 \\
5\end{array}$ & $\begin{array}{c}0.723 \\
* *\end{array}$ & $\begin{array}{c}0.511 \\
* *\end{array}$ & $\begin{array}{c}0.408 \\
* *\end{array}$ & $\begin{array}{c}- \\
0.163\end{array}$ & -0.009 & $\begin{array}{c}0.19 \\
4\end{array}$ & 1 \\
\hline
\end{tabular}

** Correlation is significant at the 0.01

\subsection{Water quality assessment by fuzzy membership}

A number of factors were considered for the assessment of water quality but only six indicators(via, $\mathrm{m}=6$ ) were selected from the list. This selection was based on their vital importance to the water quality and potential influence on human health. The representative indictors included chloride, COD, ammonia nitrogen, nitrate, fluoride, sulfates. Fuzzy comprehensive evaluation method was used to assess water environmental quality and the water quality was described under five class(Table 4) as according to China's water quality assessment standards. Through the formula $(1-1) \sim(1-6)$ calculation, the results showed that the surface water quality was class I, and the 
integrated health degree exceeded 0.85 , which means that water qualities of most samples were good and suitable for drinking and irrigation according to the water quality assessment by Fuzzy comprehensive evaluation. Some of the concentrations of ammonia nitrogen were between class I and class III with the exception of three samples (XH34,XH43,XH52) which exceeded class III. Thus, ammonia nitrogen was found to be the main pollutant in the water of Xiahe County but it was still unsuitable for drinking.

Table 4 Standard of quality classification for surface water

\begin{tabular}{ccccccc}
\hline Parameter/mg. L $^{-1}$ & & I & II & III & IV & V \\
\hline chloride & $\leq$ & 250 & 250 & 250 & 250 & 250 \\
COD & $\leq$ & 15 & 15 & 20 & 30 & 40 \\
Ammonia & $\leq$ & 0.15 & 0.5 & 1.0 & 1.5 & 2.0 \\
nitrogen & & & & & & \\
nitrate & $\leq$ & 10 & 10 & 20 & 20 & 25 \\
fluoride & $\leq$ & 1.0 & 1.0 & 1.0 & 1.5 & $>1.5$ \\
sulfate & $\leq$ & 250 & 250 & 250 & 250 & 250 \\
\hline
\end{tabular}

As far as the ammonia of surface water is concerned, there are three main sources: Firstly, biodegradable waste and the animals and plants residues; Secondly, local herders and tourists built up on daily life garbage ${ }^{[7,71]}$; Thirdly, various agricultural waste production and increasing industrial activities in Plateau pastoral area ${ }^{[72]}$. Additionally, excessive use of fertilizers, manure and pesticides may be harmful although they are used for better production and protection of crops ${ }^{[72,73]}$. However, to ensure a better quality of surface water, attention need to be paid to the following recommendations. a) The residues and dung generated by plants and animals should be recycled. b) Domestic waste arising from tourism and daily life activities of local herdsmen should be separated, recovered and treated properly. c) Related government departments should work on improving people awareness about environmental protection. It is suggested that water supply is centralized and water plants are built to ensure the quality of surface water in the pastoral areas by means of controlling of the source. Furthermore, post-treatment processes are needed to remove nitrogen from surface water by supplementing carbon resource ${ }^{[74-76]}$ allowing Plateau pastoral area people get as less affected as possible from drinking water.

\section{Conclusions}

Investigations of the hydrochemical characteristics of 69 surface water samples from Xiahe County revealed considerable variations between the analyzed parameters. Piper's Trilinear diagram shows that the hydrochemistry types in the surface water of Xiahe County is $\mathrm{HCO}_{3}-\mathrm{Mg}^{2+}-\mathrm{Ca}^{2+}$ type. Surface water chemical evolution, where the water-rock interaction processes are considered momentous in the definition of the $\mathrm{HCO}_{3}-\mathrm{Mg}^{2+}-\mathrm{Ca}^{2+}$ type visible in a Piper's diagram as shown by the dispersion in the cation $\left(\mathrm{Ca}^{2+}\right.$ and $\left.\mathrm{Mg}^{2+}\right)$ and anion $\left(\mathrm{HCO}_{3}\right)$ contents of the surface water samples. The presence of anions and cations in surface water could mainly be attributed to the weather and dissolution of carbonate rock. It could be associated with anthropogenic activities and effluents from agricultural return flow. $\mathrm{Na}^{+}$and $\mathrm{K}^{+}$are mainly due to anthropogenic input like excessive use of fertilizers use, municipal waste, sewage-sewer leaking which can end up getting into water.

The fuzzy comprehensive evaluation method showed that the surface water quality of all samples was class I, and the integrated health degree reached more than 0.85 , which indicates that water quality of most samples was in good to excellent category. The results also indicated the water is suitable for irrigation directly but not suitable for drinking unless treated otherwise through professional treatment method. Ammonia is found to be the main pollutant in surface water of Xiahe County, Thus, authorities should give importance to the pollution of ammonia to prevent deterioration of good water quality.

Additionally, this document may serve as a guide for future researchers to evaluate accurately and precisely the surface water conditions, specifically for Plateau pastoral area subjected to water 
intrusion phenomenon. The established framework for quality assessment, by means of analysis of its major physicochemical parameters, may serve as a basis for evaluating the suitability of water for drinking and irrigation purpose. The Plateau pastoral area water environmental safety should protect and maintain ecological balance as Plateau pastoral area has important theoretical and practical values.

Acknowledgments: This work was supported by the Tibetan Plateau Community Protection and Rational Utilization of Natural Grassland Technology Research and Demonstration Project(201203006), the National Natural Science Foundation of China (No.41571051), and the Fundamental Research Funds for the Central Universities in Lanzhou University (lzujbky-2015-150 and lzujbky-2016-261).

\section{Reference}

[1]Cao S, Zhang J. Political risks arising from the impacts of large-scale afforestation on water resources of the Tibetan Plateau[J]. Gondwana Research. 2015, 28(2):898-903.

[2]Huang X, Sillanpaa M, Gjessing E Tetc. Water quality in the Tibetan Plateau: major ions and trace elements in the headwaters of four major Asian rivers[J]. Sci Total Environ. 2009, 407(24):62426254 .

[3]Zhou S, Kang S, Chen Fetc. Water balance observations reveal significant subsurface water seepage from Lake Nam Co, south-central Tibetan Plateau[J]. Journal of Hydrology. 2013, 491:89-99.

[4]Aly A A, Kishk F M, Gaber H Metc. Long-term detection and hydrochemistry of groundwater resources in Egypt: Case study of Siwa Oasis[J]. Journal of the Saudi Society of Agricultural Sciences. 2016, 15(1):67-74.

[5]Ren C, Guo P, Li Metc. An innovative method for water resources carrying capacity research-Metabolic theory of regional water resources[J]. J Environ Manage. 2016, 167:139-146.

[6]Barnett T P, Adam J C, Lettenmaier D P. Potential impacts of a warming climate on water availability in snow-dominated regions[J]. Nature. 2005, 438(7066):303-309.

[7]Lu A, Ding, Y.,Pang, H.,Yuan, L.,. Impact of Global Warming on Water Resource in Arid Area of Northwest China[J]. 2005.

[8]Gao Y, Yu G, He N. Equilibration of the terrestrial water, nitrogen, and carbon cycles: Advocating a health threshold for carbon storage[J]. Ecological Engineering. 2013, 57:366-374.

[9]Chen J, Zhao X, Sheng Xetc. Formation mechanisms of megadunes and lakes in the Badain Jaran Desert, Inner Mongolia[J]. Chinese Science Bulletin. 2006, 51(24):3026-3034.

[10]Song C, Huang B, Ke Letc. Remote sensing of alpine lake water environment changes on the Tibetan Plateau and surroundings: A review[J]. ISPRS Journal of Photogrammetry and Remote Sensing. 2014, 92:26-37.

[11]Zheng M. An introduction to saline lakes on the QinghaieTibet Plateau. In: Dumont, H.J., Werger, M.J.A. (Eds.), Monograghiae Biologicae, vol. 76. Kluwer Academic Publishers, The Netherlands, ISBN 0792340981.[J]. Curr Opin Biotechnol. 1997, 33:87-94.

[12]Wu J Y. Assessing surface water quality of the Yangtze Estuary with genotoxicity data[J]. Mar Pollut Bull. 2005, 50(12):1661-1667. 
[13]Chidya R C G, Sajidu S M I, Mwatseteza J Fetc. Evaluation and assessment of water quality in Likangala River and its catchment area[J]. Physics and Chemistry of the Earth, Parts A/B/C. 2011, 36(14-15):865-871.

[14]Yang W D Q L Q. A Research on the Motivation Forces of the Natural Pasture and Sustainable Development in Xiahe County[J]. 2007.

[15]Sun W, Xia C, Xu Metc. Application of modified water quality indices as indicators to assess the spatial and temporal trends of water quality in the Dongjiang River[J]. Ecological Indicators. 2016, 66:306-312.

[16]S. SURATMAN* M I M S, Y.Y. HEE, E.A. BEDURUS \& M.T. LATIF. A Preliminary Study of Water Quality Index in Terengganu River Basin, Malaysia[J]. 2015.

[17]Cheng H, Ouyang W, Hao Fetc. The non-point source pollution in livestock-breeding areas of the Heihe River basin in Yellow River[J]. Stochastic Environmental Research and Risk Assessment. 2006, 21(3):213-221.

[18]Gyawali S, Techato K, Yuangyai Cetc. Assessment of Relationship between Land uses of Riparian Zone and Water Quality of River for Sustainable Development of River Basin, A Case Study of U-Tapao River Basin, Thailand[J]. Procedia Environmental Sciences. 2013, 17:291-297.

[19]Zampella R A, Procopio N A, Lathrop R Getc. Relationship of Land-Use/Land-Cover Patterns and Surface-Water Quality in The Mullica River Basin[J]. Journal of the American Water Resources Association. 2007, 43(3):594-604.

[20]Giri S, Qiu Z. Understanding the relationship of land uses and water quality in Twenty First Century: A review[J]. J Environ Manage. 2016, 173:41-48.

[21]Yu D, Shi P, Liu Yetc. Detecting land use-water quality relationships from the viewpoint of ecological restoration in an urban area[J]. Ecological Engineering. 2013, 53:205-216.

[22]Zhang B, Song X, Zhang Yetc. Hydrochemical characteristics and water quality assessment of surface water and groundwater in Songnen plain, Northeast China[J]. Water Res. 2012, 46(8):27372748 .

[23]Voyslavov T, Tsakovski S, Simeonov V. Hasse diagram technique as a tool for water quality assessment[J]. Anal Chim Acta. 2013, 770:29-35.

[24]Effendi H. River Water Quality Preliminary Rapid Assessment Using Pollution Index[J]. Procedia Environmental Sciences. 2016, 33:562-567.

[25]Erturk A, Gurel M, Ekdal Aetc. Water quality assessment and meta model development in Melen watershed - Turkey[J]. J Environ Manage. 2010, 91(7):1526-1545.

[26]Kazi T G, Arain M B, Jamali M Ketc. Assessment of water quality of polluted lake using multivariate statistical techniques: a case study[J]. Ecotoxicol Environ Saf. 2009, 72(2):301-309.

[27]Dinka M O, Loiskandl W, Ndambuki J M. Hydrochemical characterization of various surface water and groundwater resources available in Matahara areas, Fantalle Woreda of Oromiya region[J]. Journal of Hydrology: Regional Studies. 2015, 3:444-456.

[28] Li S, Li J, Zhang Q. Water quality assessment in the rivers along the water conveyance system of the Middle Route of the South to North Water Transfer Project (China) using multivariate statistical techniques and receptor modeling[J]. J Hazard Mater. 2011, 195:306-317.

[29]CHISWELL@ W D a B. REVIEW OF AQUATIC MONITORING PROGRAM DESIGN[J]. 
[30]Cui B-L, Li X-Y. Characteristics of stable isotopes and hydrochemistry of river water in the Qinghai Lake Basin, northeast Qinghai-Tibet Plateau, China[J]. Environmental Earth Sciences. 2014, 73(8):4251-4263.

[31]Shrestha S, Kazama F. Assessment of surface water quality using multivariate statistical techniques: A case study of the Fuji river basin, Japan[J]. Environmental Modelling \& Software. 2007, 22(4):464-475.

[32]Singh E J, Gupta A, Singh N R. Groundwater quality in Imphal West district, Manipur, India, with multivariate statistical analysis of data[J]. Environ Sci Pollut Res Int. 2013, 20(4):2421-2434.

[33]Hong X X Z L M. Discuss on cultivate tourism as a prominent industry in Xiahe County (in Chinese)[J]. 2002.

[34]Li D, Gao Q, Liu Jetc. Knowledge, attitude, and practices (KAP) and risk factors analysis related to cystic echinococcosis among residents in Tibetan communities, Xiahe County, Gansu Province, China[J]. Acta Trop. 2015, 147:17-22.

[35]Li Y. On the Xiahe County name (in Chinese)[J]. 2011.

[36]Wang J H G Z T J J C H. Evaluation on adaptability of six Avena varieties in Xiahe County,Gansu Province[J]. 2013.

[37]Wang Q, Zhang Q-p, Zhou W. Grassland Coverage Changes and Analysis of the Driving Forces in Maqu County[J]. Physics Procedia. 2012, 33:1292-1297.

[38]Shah M H, Iqbal J, Shaheen Netc. Assessment of background levels of trace metals in water and soil from a remote region of Himalaya[J]. Environ Monit Assess. 2012, 184(3):1243-1252.

[39]Awang H, Daud Z, Hatta M Z M. Hydrology Properties and Water Quality Assessment of the Sembrong Dam, Johor, Malaysia[J]. Procedia - Social and Behavioral Sciences. 2015, 195:28682873.

[40]Bo Y, Liu C, Jiao Petc. Hydrochemical characteristics and controlling factors for waters' chemical composition in the Tarim Basin, Western China[J]. Chemie der Erde - Geochemistry. 2013, 73(3):343-356.

[41]El-Sayed M, Salem W M. Hydrochemical assessments of surface Nile water and ground water in an industry area - South West Cairo[J]. Egyptian Journal of Petroleum. 2015, 24(3):277-288.

[42]SEPAC. SEPAC. State Environmental Protection Administration of China. Environmental quality standard for surface water, China(GB3838-2002). Beijing: China Environmental Science Press (in Chinese)[J]. 2002.

[43]Cheng J, Tao J-p. Fuzzy Comprehensive Evaluation of Drought Vulnerability Based on the Analytic Hierarchy Process[J]. Agriculture and Agricultural Science Procedia. 2010, 1:126-135.

[44]Ren J C D S L W H. A MODEL OF MULTI-OBJECTIVE COMPREHENSIVE EVALUATION FOR POWER PLANT PROJECTS[J]. 2002.

[45]Liu Y, Fang P, Bian Detc. Fuzzy comprehensive evaluation for the motion performance of autonomous underwater vehicles[J]. Ocean Engineering. 2014, 88:568-577.

[46]Dahiya S, Singh B, Gaur Setc. Analysis of groundwater quality using fuzzy synthetic evaluation[J]. J Hazard Mater. 2007, 147(3):938-946.

[47]Liu L, Zhou J, An Xetc. Using fuzzy theory and information entropy for water quality assessment in Three Gorges region, China[J]. Expert Systems with Applications. 2010, 37(3):25172521. 
[48]WANG Jian-Hua L X-G, JIANG Ming,LI Xiao-Yan and TIAN Jing-Han. Fuzzy Synthetic Evaluation of Wetland Soil Quality Degradation: A Case Study on the Sanjiang Plain, Northeast China*1[J]. 2009.

[49]Piplani R, Wetjens D. Evaluation of entropy-based dispatching in flexible manufacturing systems[J]. European Journal of Operational Research. 2007, 176(1):317-331.

[50]E. Ertugrul Karsak* E T. Fuzzy multi-criteria decision-making procedure for evaluating advanced manufacturing system investments[J].

[51]Shan Feng a L D X b. Decision support for fuzzy comprehensive evaluation of urban development[J]. 1999.

[52]Guo L, Gao J, Yang Jetc. Criticality evaluation of petrochemical equipment based on fuzzy comprehensive evaluation and a BP neural network[J]. Journal of Loss Prevention in the Process Industries. 2009, 22(4):469-476.

[53]G.Annadurai S R B, V.R.Srinivasamoorthy. Mathematical modeling of phenol degradation system using fuzzy comprehensive evaluation [J]. 2000.

[54]Pan Jun Meng Li Z Z. The Method of Quadratic Combination Weighting Fuzzy Comprehensive Evaluation applied in Water Quality Assessment[J]. 2014.

[55]Bi X, Isaili R A M, Zheng Q. Evaluation of Wastewater Treatment Quality in the West BankPalestine Based on Fuzzy Comprehensive Evaluation Method[J]. 2015:219-221.

[56]Zhou Z, Zhang X, Dong W. Fuzzy Comprehensive Evaluation for Safety Guarantee System of Reclaimed Water Quality[J]. Procedia Environmental Sciences. 2013, 18:227-235.

[57]Gharibi H, Mahvi A H, Nabizadeh Retc. A novel approach in water quality assessment based on fuzzy logic[J]. J Environ Manage. 2012, 112:87-95.

[58]Environment M o t. SURFACE WATER QUALITY TRENDS IN ONTARIO 1964 - 1979[J].

[59]Simões F d S, Moreira A B, Bisinoti M Cetc. Water quality index as a simple indicator of aquaculture effects on aquatic bodies[J]. Ecological Indicators. 2008, 8(5):476-484.

[60]Akkoyunlu A, Akiner M E. Pollution evaluation in streams using water quality indices: A case study from Turkey's Sapanca Lake Basin[J]. Ecological Indicators. 2012, 18:501-511.

[61]Hoseinzadeh E, Khorsandi H, Wei Cetc. Evaluation of Aydughmush River water quality using the National Sanitation Foundation Water Quality Index (NSFWQI), River Pollution Index (RPI), and Forestry Water Quality Index (FWQI)[J]. Desalination and Water Treatment. 2014, 54(11):2994-3002.

[62]Gautam S K, Maharana C, Sharma Detc. Evaluation of groundwater quality in the Chotanagpur plateau region of the Subarnarekha river basin, Jharkhand State, India[J]. Sustainability of Water Quality and Ecology. 2015, 6:57-74.

[63]Hoko Z. An assessment of the water quality of drinking water in rural districts in Zimbabwe. The case of Gokwe South, Nkayi, Lupane, and Mwenezi districts[J]. Physics and Chemistry of the Earth, Parts A/B/C. 2005, 30(11-16):859-866.

[64]Mohapatra M, Anand S, Mishra B Ketc. Review of fluoride removal from drinking water[J]. J Environ Manage. 2009, 91(1):67-77.

[65]Organization W H. Guidelines for Drinking Water Quality Third Edition incorporating first and second addenda[J]. 2008. 
[66]Annapoorna H, Janardhana M R. Assessment of Groundwater Quality for Drinking Purpose in Rural Areas Surrounding a Defunct Copper Mine[J]. Aquatic Procedia. 2015, 4:685-692.

[67]Venkateswaran S, Deepa S. Assessment of Groundwater Quality using GIS Techniques in Vaniyar Watershed, Ponnaiyar River, Tamil Nadu[J]. Aquatic Procedia. 2015, 4:1283-1290.

[68]Ebrahimi M, Kazemi H, Ehtashemi Metc. Assessment of groundwater quantity and quality and saltwater intrusion in the Damghan basin, Iran[J]. Chemie der Erde - Geochemistry. 2016.

[69]Srinivasamoorthy K, Gopinath M, Chidambaram Setc. Hydrochemical characterization and quality appraisal of groundwater from Pungar sub basin, Tamilnadu, India[J]. Journal of King Saud University - Science. 2014, 26(1):37-52.

[70]Hu Z, Wang L, Wang Zetc. Quantitative assessment of climate and human impacts on surface water resources in a typical semi-arid watershed in the middle reaches of the Yellow River from 1985 to 2006[J]. International Journal of Climatology. 2015, 35(1):97-113.

[71]Cong Z, Yang D, Gao Betc. Hydrological trend analysis in the Yellow River basin using a distributed hydrological model[J]. Water Resources Research. 2009, 45.

[72]Liu H, Hu Y, Qi Setc. Organochlorine pesticide residues in surface water from Sichuan Basin to Aba Prefecture profile, east of the Tibetan Plateau[J]. Frontiers of Earth Science. 2014, 9(2):248-258.

[73]Darko G, Akoto O, Oppong C. Persistent organochlorine pesticide residues in fish, sediments and water from Lake Bosomtwi, Ghana[J]. Chemosphere. 2008, 72(1):21-24.

[74]Li P, Li M, Zhang Yetc. The treatment of surface water with enhanced membrane-aerated biofilm reactor (MABR)[J]. Chemical Engineering Science. 2016, 144:267-274.

[75]Chu L, Wang J. Nitrogen removal using biodegradable polymers as carbon source and biofilm carriers in a moving bed biofilm reactor[J]. Chemical Engineering Journal. 2011, 170(1):220225 .

[76]Guerrero J, Taya C, Guisasola Aetc. Glycerol as a sole carbon source for enhanced biological phosphorus removal[J]. Water Res. 2012, 46(9):2983-2991.

(C) 2016 by the authors; licensee Preprints, Basel, Switzerland. This article is an open access article distributed under the terms and conditions of the Creative Commons by Attribution (CC-BY) license (http://creativecommons.org/licenses/by/4.0/). 